\title{
PEMBELAJARAN DARING BERVARIASI DI MASA COVID-19 UNTUK MENINGKATKAN KEAKTIFAN PESERTA DIDIK SMPN 4 MATARAM
}

\author{
YUNIAR HAYATI \\ SMPN 4 Mataram, kec, Cakranegara, Mataram \\ hayatiyuniar@gmail.com
}

\begin{abstract}
ABSTRAK
Best Practice disusun dengan tujuan untuk mengetahui peningkatan keaktifan peserta didik dalam pembelajaran Daring Mapel Pendidikan Agama Islam Kelas VIII SMPN 4 Mataram selama masa pandemi Covid-19. Praktik terbaik dilaksanakan pada semester Ganjil Tahun Pelajaran 2020/2021 yaitu bulan Juli sampai Desember 2020. KTI ini menggambarkan tentang peningkatan keaktifan peserta didik selama mengikuti pembelajaran Daring yang bervariasi. Media pembelajaran yang digunakan antara lain; Zoom Meeting, Google Meet, Power Point, Video, Pixton dan lain sebagainya. Data menggunakan Dokumentasi yang terdiri dari Respon berupa pengumpulan tugas-tugas peserta didik, Absensi dan Cheklist Variabel kegiatan. Subyek penelitian kelas VIII.1-VIII.8, 177 orang. Kesimpulan: keaktifan peserta didik meningkat mulai pembelajaran Bab 1 sampai dengan Bab 7 sebesar 57,56 \% yaitu 102 orang aktif dalam merespon tugas-tugas dan 58,40\% yaitu 103 orang aktif mengabsen. Rata-rata 103 orang aktif, 74 orang tidak aktif.
\end{abstract}

Kata Kunci : Pembelajaran Daring, Covid-19, keaktifan siswa.

\section{PENDAHULUAN}

Penghujung tahun 2019 merupakan tragedi besar yang meluluhlantakkan tatanan negara-negara dunia di bawah kungkungan virus Covid-19. Pandemi Covid19 telah memaksa kita semua mencari jalan alternatif untuk bertahan hidup dalam keterbatasan. Bagi dunia pendidikan menuntut untuk tetap bisa menyelenggarakan pendidikan bagi peserta didik walau dengan Pembelajaran Jarak Jauh, sebagaimana tercantum dalam Surat Edaran Mendikbud Nomor 4 Tahun 2020 (Direktorat sekolah menengah pertama kementerian pendidikan dan kebudayaan, 2020) tentang Pelaksanaan Kebijakan Pendidikan dalam Masa Darurat Penyebaran Covid-19 bahwa proses Belajar dari Rumah (BDR) melalui Pembelajaran Daring/ Jarak Jauh (PJJ) dilaksanakan untuk memberikan pengalaman belajar yang bermakna bagi siswa, tanpa terbebani tuntutan menuntaskan seluruh capaian kurikulum untuk kenaikan kelas maupun kelulusan. Dan aktivitas Pembelajaran bervariasi antar siswa, sesuai minat dan kondisi masing-masing termasuk mempertimbangkan kesenjangan akses/ fasilitas belajar di rumah.

Untuk membantu para guru menambah wawasan dan kemampuan dalam menyatukan komputasi dan komunikasi berkecepatan tinggi untuk data, suara dan video, maka SMPN 4 Mataram mengadakan workshop tentang IT pada awal tahun pelajaran 2020/2021. Sementara dari peserta didik kami SMPN 4 Mataram, ada yang belum paham cara bergabung di kelas online Google Classroom dan Google Form, 
dan belum tersedianya sarana prasarana baik gawai android dan kuota internet. Karena tidak semua peserta didik memiliki gawai dan berasal dari keluarga mampu. Tetapi kami tetap menghargai upaya mereka yang meminjam gawai teman atau tetangga untuk mengerjakan tugas dengan segala keterbatasannya. Hingga ada yang berupaya datang ke sekolah untuk meminta print out materi dan mengikuti Ulangan Tengah Semester Ganjil/ Penilaian Akhir Semester Ganjil. Peserta didik memiliki latar belakang sosial ekonomi yang berbeda-beda dan kemampuan akademik yang bervariasi. Sekolah berada di wilayah kecamatan Cakranegara sebagai tempat pusat perbelanjaan dan kelurahan Karang Taliwang sebagai daerah pariwisata kuliner. Namun kondisi Pandemi saat ini sangat berimplikasi terhadap kondisi sosial ekonomi perserta didik. Di samping itu kurangnya dukungan orang tua yang berperan sebagai pengganti guru di rumah yang memotivasi belajar anak-anaknya, serta kurangnya minat belajar peserta didik terhadap pembelajaran Daring. Hal ini bisa dilihat ketika pertama kali diberlakukannya Pembelajaran Jarak Jauh/ PJJ atau Daring pada awal pandemi-Covid-19 yaitu bulan Maret 2019. Faktor-faktor tersebut yang mendorong untuk menulis Best Practice ini.

\section{METODE PELAKSANAAN}

Penulis memilih pembelajaran Daring bervariasi sebagai praktek terbaik yang sangat sesuai dengan kondisi pandemic Covid-19, dan model Pembelajaran Jarak Jauh (online) di mana peserta didik melaksanakan Belajar Dari Rumah. Best Practice menggambarkan tentang keadaan atau fenomena tertentu dari obyek Best Practice yang didapat setelah melaksanakan kegiatan dan melihat hasil dokumentasi berupa respon, absensi, jadwal, foto/ screenshoot kegiatan, materi pelajaran, media pembelajaran dan lain-lain. Kesimpulan Best Practice digambarkan dalam bentuk tabel dan grafik, agar mempermudah penulis dan orang lain untuk memahaminya.

Best Practice dilaksanakan pada Semester Ganjil Tahun Pelajaran 2020/2021 mulai tanggal 13 Juli sampai 19 Desember 2020. Tempat pelaksanaan Best Practice adalah SMPN 4 Mataram, Jalan RA. Kartini No.30 Karang Taliwang, Cakranegara, Mataram, NTB. Bahan yang digunakan untuk Best Practice adalah model pembelajaran Daring dengan menggunakan media pembelajaran berupa aplikasi daring/ online yaitu WhatsApp, Meeting Live (Zoom Meeting dan Google Meet), Video Pembelajaran, WPS Letter, Power Point, PDF, Google Classroom, Google Form, Youtube dan Pixton. Materi yang digunakan untuk pembelajaran daring adalah materi pendidikan agama islam kelas 8 semester Ganjil.

\section{HASIL DAN PEMBAHASAN}

Respon Peserta Didik terhadap pembelajaran Daring bisa dilihat dari gambar grafik 1 di bawah ini yang menggambarkan seberapa aktif peserta didik dalam mengerjakan tugas-tugas yang diberikan. Grafik batang yang berwarna biru menunjukkan jumlah peserta didik yang aktif dan yang berwarna merah menunjukkan peserta didik yang tidak aktif dalam setiap Bab, mulai Bab 1 sampai dengan Bab 7. Grafik tersebut menunjukkan adanya peningkatan keaktifan peserta didik pada setiap pembelajaran mulai dari Bab 1 sampai dengan Bab 7. 


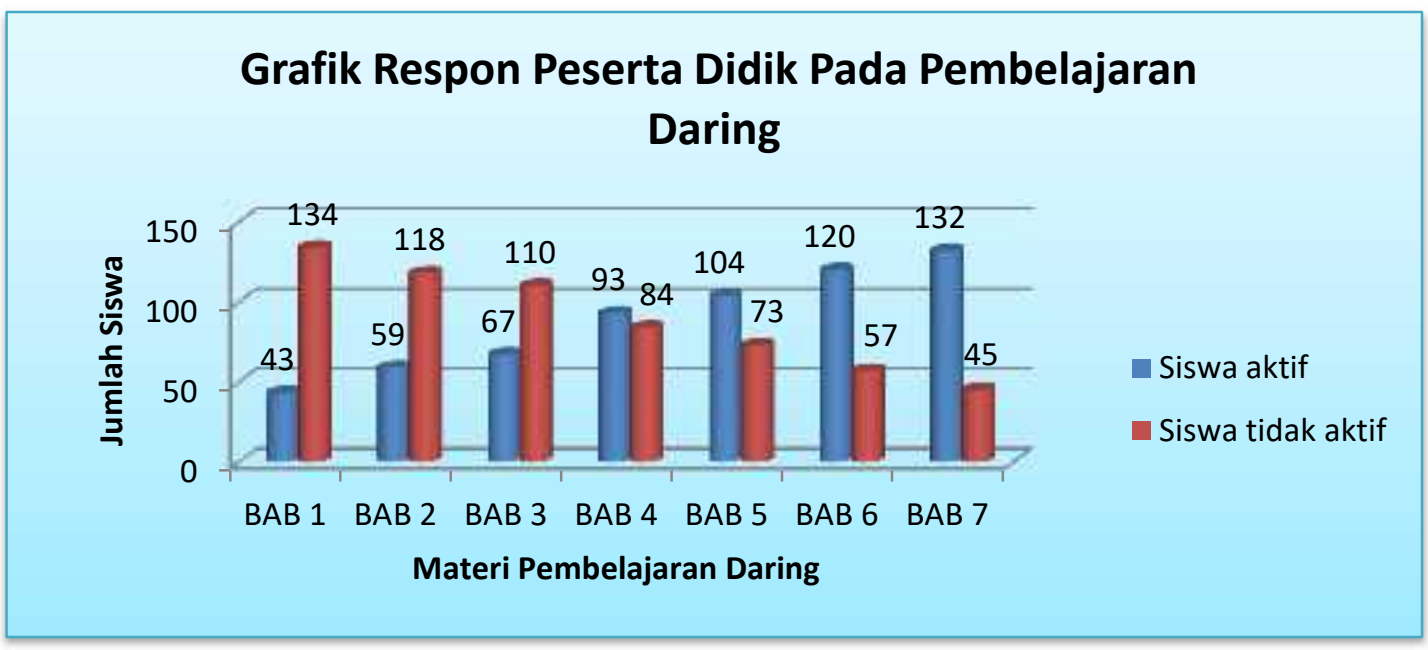

Grafik 1. Respon Peserta Didik Pada Pembelajaran Daring

Absensi Peserta Didik pada pembelajaran Daring bisa dilihat dari gambar grafik 2 yang menggambarkankan seberapa aktif peserta didik dalam mengikuti pembelajaran Daring. Grafik batang yang berwarna oranye menunjukkan peserta didik yang aktif dan yang berwarna kuning muda menunjukkan yang tidak aktif, dalam setiap Bab. Grafik tersebut menunjukkan adanya peningkatan keaktifan peserta didik mulai dari Bab 1 sampai dengan Bab 7.

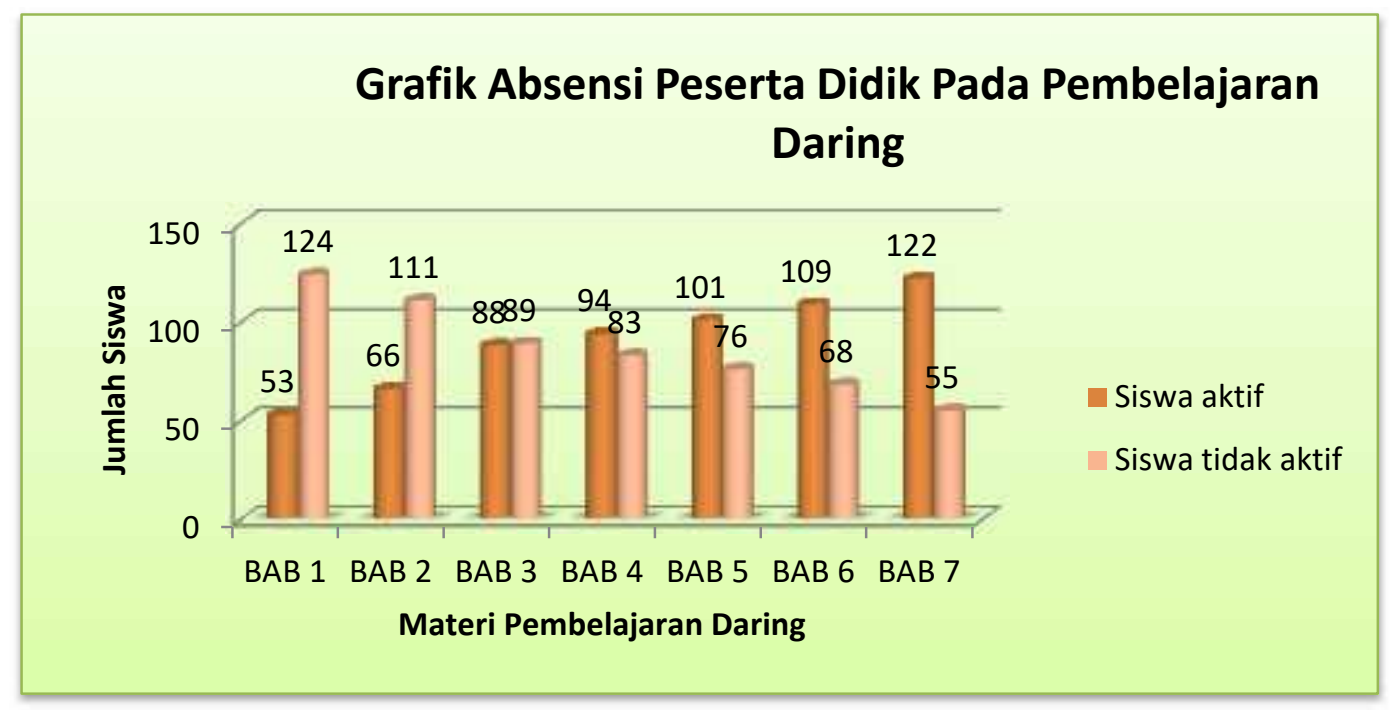

Grafik 2. Absensi Peserta Didik Pada Pembelajaran Daring 
Tabel 1 berikut menunjukkan tentang daftar variable kegiatan yang digunakan dalam melaksanakan pembelajaran Daring selama satu semester.

Tabel 1 Daftar variabel pelaksanaan pembelajaran Daring

\begin{tabular}{|c|c|c|c|c|c|}
\hline No & Hari/ Tanggal & Materi Pokok & $\begin{array}{l}\text { Aplikasi } \\
\text { yang } \\
\text { digunakan }\end{array}$ & $\begin{array}{c}\text { Bentuk } \\
\text { Tugas }\end{array}$ & $\begin{array}{l}\text { Bentuk } \\
\text { Respon }\end{array}$ \\
\hline 1. & $\begin{array}{l}\text { Senin, 27 Juli } \\
\text { 2020, } 3 \text { Agustus } \\
2020,10 \\
\text { Agustus 2020, } \\
17 \text { Agustus 2020 }\end{array}$ & $\begin{array}{l}\text { Bab 1, Iman kepada } \\
\text { Kitab-kitab Allah } \\
\text { SWT. }\end{array}$ & $\begin{array}{c}\text { Ada } \\
\text { (meeting } \\
\text { zoom, google } \\
\text { meet, video, } \\
\text { youtube } \\
\text { PDF,komik } \\
\text { pixton, } \\
\text { google } \\
\text { classroom, } \\
\text { google form) }\end{array}$ & $\begin{array}{c}\text { Ada } \\
\text { (foto selfie, } \\
\text { meringkas, } \\
\text { menjawab } \\
\text { soal, } \\
\text { membuat } \\
\text { video) }\end{array}$ & $\begin{array}{l}\text { Ada } \\
\text { (foto } \\
\text { selfie, } \\
\text { absen, } \\
\text { mengump } \\
\text { ulkan } \\
\text { tugas, } \\
\text { bertanya } \\
\text { dll) }\end{array}$ \\
\hline 2. & $\begin{array}{l}\text { Senin, } 24 \\
\text { Agustus 2020, } \\
31 \text { Agustus 2020 }\end{array}$ & $\begin{array}{l}\text { Bab 2, Menghindari } \\
\text { minuman keras, judi } \\
\text { dan pertengkaran }\end{array}$ & ada & ada & ada \\
\hline 3. & $\begin{array}{l}\text { Senin, } 7 \\
\text { September } 2020\end{array}$ & $\begin{array}{l}\text { Bab 3, Kejujuran dan } \\
\text { keadilan }\end{array}$ & ada & ada & ada \\
\hline 4. & $\begin{array}{l}\text { Senin, } 14 \\
\text { September } 2020 \text {, } \\
21 \text { September } \\
2020,5 \text { Oktober } \\
2020,19 \\
\text { Oktober } 2020\end{array}$ & $\begin{array}{l}\text { Bab 4, Macam-macam } \\
\text { Shalat Sunah }\end{array}$ & ada & ada & ada \\
\hline 5. & $\begin{array}{l}\text { Senin, } 26 \\
\text { Oktober } 2020,2 \\
\text { November } 2020\end{array}$ & $\begin{array}{l}\text { Bab 5, Macam-macam } \\
\text { Sujud }\end{array}$ & ada & ada & ada \\
\hline 6. & $\begin{array}{l}\text { Senin, } 9 \\
\text { November } 2020 \text {, } \\
16 \text { November } \\
2020\end{array}$ & $\begin{array}{l}\text { Bab 6, Iptek masa } \\
\text { Bani Umayyah }\end{array}$ & ada & ada & ada \\
\hline 7. & $\begin{array}{l}\text { Senin, } 23 \\
\text { November } 2020\end{array}$ & $\begin{array}{l}\text { Bab 7, Hemat, rendah } \\
\text { hati dan sederhana }\end{array}$ & ada & ada & ada \\
\hline 8. & $\begin{array}{l}\text { Senin, } 28 \\
\text { September 2020, } \\
23 \text { November } \\
2020\end{array}$ & $\begin{array}{l}\text { Ulangan Harian } 2, \\
\text { Praktek bacaan sujud }\end{array}$ & ada & ada & ada \\
\hline 9. & $\begin{array}{l}\text { Senin, } 12 \\
\text { Oktober } 2020\end{array}$ & $\begin{array}{l}\text { Penilaian Tengah } \\
\text { Semester Ganjil } \\
2020 / 2021\end{array}$ & ada & ada & ada \\
\hline
\end{tabular}




\begin{tabular}{|c|l|l|c|c|c|}
\hline 10. & $\begin{array}{l}\text { Jumat, 4 } \\
\text { Desember 2020 }\end{array}$ & $\begin{array}{l}\text { Penilaian Akhir } \\
\text { Semester Ganjil } \\
2020 / 2021\end{array}$ & ada & ada & ada \\
\hline
\end{tabular}

\section{B. Pembahasan}

Definisi Media Daring dalam Wikimedia Indonesia (2020) adalah media dalam jaringan online yang berhubungan dengan teknologi dan internet. Arti Daring menurut KBBI (2020) adalah terhubung melalui jejaring computer, internet dan sebagainya. Arti Daring juga dapat diartikan sebagai suatu keadaan komputer yang dapat saling bertukar informasi karena sudah terhubung ke sebuah internet. Bilfaqih dan Qomarudin (2015) menyatakan pembelajaran Daring merupakan program penyelenggaraan kelas pembelajaran dalam jaringan untuk menjangkau kelompok target yang massif dan luas. Pembelajaran Daring adalah metode belajar yang menggunakan model interaktif berbasis internet dan Learning Management System (LMS) seperti Zoom, Google Meet dan sebagainya.

Pengajaran sebagai perpaduan dari dua aktivitas, yaitu: aktivitas mengajar dan aktivitas belajar. Keaktifan belajar peserta didik merupakan unsur dasar yang penting bagi keberhasilan proses pembelajaran. Melvin L. Silberman (2010: 5) mengatakan saat belajar aktif, para siswa melakukan banyak kegiatan. Mereka menggunakan otak untuk mempelajari ide-ide, memecahkan masalah dan menerapkan apa yang mereka pelajari. Kemampuan belajar mandiri merupakan tujuan akhir dari belajar aktif (Eveline dan Hartini, 2010: 106). Pembelajaran aktif dimaksudkan untuk mengoptimalkan penggunaan semua potensi yang dimiliki oleh anak didik, sehingga semua anak didik dapat mencapai hasil belajar yang memuaskan. Pembelajaran yang menuntut keterlibatan siswa ini sesuai dengan Kurikulum yang berlaku pada negara Indonesia yaitu menggunakan kurikulum 2013 revisi yang menekankan pada peran aktif siswa dan guru sebagai fasilitator dalam proses pembelajaran (Kurniasih \& Sari, 2014).

Keaktifan peserta didik dalam kegiatan belajar tidak lain adalah untuk mengkonstruksi pengetahuan mereka sendiri. Mereka aktif membangun pemahaman atas persoalan atau segala sesuatu yang mereka hadapi dalam proses pembelajaran. Pengertian aktif dalam Wikipedia adalah istilah umum yang merujuk kepada sesuatu yang sedang dan dapat bergerak, bekerja, atau menjalankan fungsinya. Dalam KBBI (2017) aktif berarti giat (bekerja, berusaha), dinamis atau bertenaga. Makna keaktifan yaitu kegiatan; kesibukan. .

Agar Pendidikan Agama Islam dan Budi Pekerti dapat melaksanakan fungsinya sebagai agen perubahan (agent of culture) dan bermanfaat bagi manusia itu sendiri terutama peserta didik, maka perlu model pembelajaran Daring yang variatif agar peserta didik aktif dalam pembelajaran. Oleh karena itu pembelajaran Daring memberikan manfaat (Bilfaqih dan Qomarudin, 2015) yaitu : 1. Meningkatkan mutu pendidikan dan pelatihan. 2. Meningkatkan keterjangkauan pendidikan dan pelatihan 3. Menekan biaya penyelenggaraan pendidikan dan pelatihan yang bermutu. Manfaat pembelajaran Daring menurut Ojat Darojat Rektor Universitas Terbuka (2020), antara lain : 1. Potensi guru akan bertambah melalui digitalisasi pendidikan. 2. Belajar dapat 
dilakukan di mana saja dan kapan saja. 3. Belajar dapat disesuaikan dengan kapasitas masing-masing siswa. 4. Belajar online/ Daring juga dapat mengedepankan inisiatif dan indepedensi siswa. 5. Interaksi siswa dan guru tidak terbatas, dapat dilakukan selama 24 jam sehingga dapat meningkatkan kualitas belajar siswa. Oleh karena itu pembelajaran Daring sangat tepat digunakan pada masa pandemi saat ini, terutama di SMPN 4 Mataram.

Pembelajaran yang mengacu pada standar proses pendidikan harus mampu memfasilitasi pengembangan potensi siswa, maka diperlukan proses pembelajaran yang mengarah pada penekanan aktivitas belajar ke arah siswa sehingga siswa secara aktif dapat mengembangkan potensi yang mereka miliki (Budiningsih, 2005). Peserta didik yang menemukan sendiri pengetahuannya, maka hasil yang diperoleh akan bertahan lama dalam ingatan dan tidak mudah dilupakan (Suryosubroto, 2009). Sehingga peserta didik mampu menyerap materi pembelajaran dengan baik dan dapat mengimplementasikan ilmunya dalam kehidupan sehari-hari.

\section{KESIMPULAN}

Hasil dari seluruh data-data yang diperoleh menunjukkan bahwa pembelajaran Daring dapat meningkatkan keaktifan peserta didik yaitu :

A. Respon sebesar 50,8 $+25,2+25,9=101,9$ atau 102 orang

B. Absensi sebesar 49,7 $+24,7+29=103,4$ atau 103 orang

C. Rata-rata tingkat keaktifan siswa secara keseluruhan 103 orang setiap pembelajaran Daring.

Maka dari itu pembelajaran Daring perlu ditingkatkan kualitasnya untuk kemajuan peserta didik dalam rangka mengantisipasi keadaan darurat pandemi Covid-19 dan menghadapi tuntutan jaman era industry 4.0 (Milenial).

Pembelajaran Daring/ Pembelajaran Jarak Jauh ini sangat berdampak kepada seluruh warga sekolah SMPN 4 Mataram, antara lain bagi peserta didik dapat menumbuhkan sikap mandiri dan rasa tanggung jawab serta mendorong untuk aktif melakukan proses belajar. Bagi Guru dapat memotivasi guru dalam meningkatkan kualitas keilmuan terutama tentang pembelajaran Daring dan menggali kreatifitas untuk menghadirkan pembelajaran yang bervariasi. Bagi orang tua yaitu melatih kepekaan dan kepedulian terhadap pendidikan putra-putrinya dan berperan aktif mengarahkan dan membimbingnya dalam proses Belajar Dari Rumah (BDR).

Terima kasih yang sebesar-besarnya kepada kepala sekolah, para pembimbing, teman sejawat dan semua pihak yang telah membantu penulisan Best Practice. Semoga menjadi amal jariyah bagi kita semua. Amin.

\section{DAFTAR PUSTAKA}

Bilfaqih, Yusuf. Qomarudin, M. Nur. 2015. Esensi Pengembangan Pembelajaran Daring. Yokyakarta: Deepubilsh, CV. Budi Utama

Budiningsih, A. (2005). Belajar Pembelajaran. Jakarta: PT Cipta dan Rineka. Depdikbud. 2002. Kamus Besar Bahasa Indonesia. Jakarta : PN. Balai Pustaka 
Direktorat sekolah menengah pertama kementerian pendidikan dan kebudayaan. 2020, kebijakan pelaksanaan pembelajaran dan penilaian pada masa pandemic covid-19.

https://kbbi.web.id/aktif.html. Kamus versi online/daring (dalam jaringan). Pengertian aktif.

Kurniasih, I \& Sari. (2014). Implementasi kurikulum konsep \& penerapan. Surabaya: Kata Pena.

Manizar, E. 2017. Optimalisasi pendidikan agama islam di sekolah. jurnal.radenfatah.ac.id.Diakses 18 Desember 2020

Pendidikan jarak jauh metode pembelajaran dari jarak jauh. Aktif. id.m.wikipedia.org. Diakses 19 Desember 2020

Silberman, M. L. (2006). Active Learning : 101 Strategi Pembelajaran Aktif (terjemahan). Bandung: Nuansa

Siregar, Eveline dan Hartini Nara. (2010). Teori Belajar dan Pembelajaran. Jakarta: Ghalia Indonesia

Suryosubroto. (2009). Proses Belajar Mengajar di Sekolah. Jakarta: Rineka Cipta. 